\title{
5. 肝硬変に対する肝移植一ウイルス性肝硬変を中心に
}

\begin{abstract}
菅原 寧彦 幕内 雅敏
要 旨：2004 年: 1 月より生体肝移植の保険適応疾患が拡大され, 成人症例での肝移植の需要が 増加してきている．特に，肝炎ウイルスを背景とした朋硬変症例の増加が著しい．肝炎症例で は, 術後のウイルス制御が大きな課題となっている，B 型肝炎再感染対策においてはまず，移 植前に，ラミブジンの内服を始め, 血液中 B 型肝炎ウイルス D N A を陰性化させておくことが 朋要である. 術後の再感染予防は, 抗 B 型肝炎ウイルス免疫グロブリンの多量投与とラミブジ ンの併用療法が標準治療となっている。一方，C型肝炎では問題点が多い．再発症例に対して はペグインターフェロンとリバビリンとの併用を行う。ただし, 併用療法は副作用が強く, 移 植前投与は一般的でない。 また持続陰性化率が低いことから, 術後投与や一予防投与に関しては コンセンサスが得られていない.

索引用語： ラミブジンインターフェロンリバビリンＢ型肝炎Ｃ 型肝炎
\end{abstract}

\section{はじめに}

近年, 生体肝移植の成人症例数の增加が著しい. 本 邦では原発性胆汁性肝硬変, 胆道閉鎖術後などの胆汁 瞇滞性肝疾患が多かったが, 近年では, 保険適応の改 正をうけて, ウイルス性肝硬変に対する症例が次第に 增加している。非ウイルス性の疾患と同様な成績を期 待するためには, 並存する肝炎ウイルスに対する治療 方針を工夫していく必要がある. 本稿では, 最近の主 な論点となっている, B 型肝炎 (HBV), C 型肝炎 (HCV) 陽性症例の移植前後の管理方法及びその成績に ついて，自験例と文献的な考察を中心に解説する。

\section{I. $\mathrm{HBV}$}

\section{1 移植前処置}

B 型肝炎再感染対策においては, 術前の HBV DNA 値が術後の再感染率を決定する1)ことは古くから知られ ていた. HBV DNA は複製の際に RNA 中間体を介し て逆転写される。逆転写醉素阻害剤の一つであるラミ ブジンは, 有効な抗 HBV 薬であり, 末期肝硬変患者で も副作用が少ない。したがって, 移植前にラミブジン の内服を始め, 血液中 HBV を陰性化させておくことは, 術後の再感染予防に扔いて有利である.

ところが，ラミブジンは長期に服用すると変異株が 出現し, いわゆる virologic breakthrough を誘発する。 - ·般的に「子想される」移植時期の 6 力月前からのラ

東京大学人:縅器移植外科
ミブジン開始が望ましい2）とされているが，脳死肝移植 では実際にいつグラワトが入手できるか明確にわから ないため, ラミブジンの適切な開始時期を決定するこ とは困難である. 本邦のように, 脳死体からのグラフ トが極めて出現しにくい状況では, ラミブジンを移植 前に使用するかどうかの判断が特に難しいと思われる.

生体肝移植はほとんどの場合(劇症肝炎以外), 待機 的手術である。したがって，生体肝移植ではラミブジ ンを適切な期間投与することで変異株出現のリスクを 負うことなく, 毃い確率で血中 HBV DNA を陰性化さ せることが可能である。これは脳死肝移植では期待で きない, 大きな利点である. $\mathrm{s}$ 抗体陽性のドナーからの 移植では，レシピエントはラミブジン投与だけで， $\mathrm{s}$ 抗 体が自然と陽性化する (adoptive immunity transfer) とするデー夕3)もある. 生体肝移植では, ドナーにあら かじめ能動免疫しておくことも可能である。 その有用 性に関しては今後のデー夕集積を待ちたい.

\section{2. 移植後治療}

免疫グロブリン (HBIG) を短期で中止すると速やかに 肝炎が再発することは古くから知られている4)。一方 HBIG は高価であり，経済的な側面も無視できない. さらにその原料を七ト血液に依存しているため, 供給 量に限界がある。このような背景から再発しない程度 に, しかも HBIG 使用量, コストを最小限に抑えるべ く,さまざまな丁大が試みられてきた。術前の $\mathrm{HBV}$ DNAにより,たとえば陽性なら HBVs抗体值 
Table 1 Response to hepatitis B virus vaccine in patients transplanted for $\mathrm{HBV}$-related liver disease

\begin{tabular}{|c|c|c|c|c|}
\hline & Sanchez-Fueyo 10,11 ) & Barcena 12) & Angelico 22$)$ & Bienzle ${ }^{13)}$ \\
\hline No of patients & 22 & 5 & 17 & 20 \\
\hline Men : women & $15: 7$ & $5: 0$ & $15: 2$ & $18: 2$ \\
\hline Age (median) & $38^{*}, 41^{* *}$ & NA & 53 & 54 \\
\hline Acute : chronic & $8: 14$ & NA & $0 / 17$ & $2 / 18$ \\
\hline Immunosuppression (mono : multi) & $11: 6$ & $5 / 0$ & $17 / 0$ & $16 / 4$ \\
\hline With HIBIG & No & No & No & Yes \\
\hline $\begin{array}{l}\text { Cut off } \mathrm{HbsAb}(\mathrm{IU} / l) \text { level } \\
\text { of sero-conversion }\end{array}$ & 10) & 10 & 100 & 500 \\
\hline $10 \mathrm{IU} / l(\%)$ & 64 & 80 & 18 & - \\
\hline$>100 \mathrm{IU} / l(\%)$ & 24 & NA & 12 & - \\
\hline $500 \mathrm{IU} / l(\%)$ & 9 & NA & 6 & 80 \\
\hline $\begin{array}{l}\text { Maximum } \mathrm{HBs} \text { Ab level } \\
\text { (medain, } \mathrm{IU} / l \text { ) in responders }\end{array}$ & 47 & NA & 258 & 25344 \\
\hline $\begin{array}{l}\text { Observation period after } \\
\text { vaccine (median, month) }\end{array}$ & 41 & 5.5 & 66 & 13.5 \\
\hline $\begin{array}{l}\text { Duration between transplantation } \\
\text { to vaccine (median, month) }\end{array}$ & 33 & $>20$ & 48 & 78 \\
\hline
\end{tabular}

(HbsAb) $500 \mathrm{IU} / l ，$ 陰性なら $100 \mathrm{IU} / l$ といったよう に，状態によって使用量を変える試み5)，あるいは最初 の 1 年を併肺しその後, ラミブジン単独で対処する方 法6)も使用量を抑える方法の一つである.ラミブジンを 併用すれば，さらに HBIGの使用量を抑えられる可能 性がある。現在では，HBIG+ラミブジンの併用が一般 的である.

教室では，ラミブジン長期投与による，变異株出現 のリスクを考虑し，術後は原則として，HBIGのみで 管理している7)。術後 1 年は HBs 抗体価が $1000 \mathrm{IU} / l$ 以上になるように，それ以降は $200 \mathrm{IU} / l$ 程度になるよ うに HBIGの投与量を決定している. 術後 1 年 1000 IU $/ l$ という抗体価設定は高めである. 術後 1 年では 1 カ月あたり，約 6000-10000 IU，それ以降では 2000-$4000 \mathrm{IU}$ の HBIG の投与が必要であった。 2005 年 3 月 までの B 型肝炎陽性, 待機手術症例は 35 例で，うち 1 例に再発を経験している。本邦に扔いては，B 型肝炎 肝硬変に対する生体肝移植は保険適匛になっているに もかかわらず，移植に当たって必須と考えられる HBIG が，保険適応になっていない点が大きな問題となって いる。

ラミブジン単独投与では $30 \%$ 程度の再発は覚悟しな くてはならない8)。この場合, YMDD変異株に対して は, adefovir dipivoxil が有効であり，かつ adefovirの 副作用も重篤なものは少なそうである99. Adefovir は
2005 年から本邦でも保険承認されているが，長期投与 の結果については必ずしも明らかではない.

\section{3. 能動免疫への期待}

HBIG は経済的な問題が大きく，ラミブジン単独で は変異株の出現を舆視できない. 近年は 6 力月以上経 過した患者に対する能動免疫の試みがなされている (Table 1). Sanchez-Fueyo 10,11) や Barcena 12) らは, 通常の B 型肝炎ワクチンを倍量投与することで，効率 に能動免疫を誘導するとしたが，ほとんどの症例では $\mathrm{HBs}$ 抗体値は $10 \mathrm{IU} / l$ 程度にとどまっていた。近年， Bienzle 13) らはワクチンを改良することで，高率に高い HBs 抗体値を誘導できるとした。今後の症例の集積が 待たれる。

\section{II . $\mathbf{H C V}$}

\section{1. 移植前治療}

HCV のほとんどは肝内に存在するため, 手術前に, 血液中の C 型肝炎ウイルスを駆除しょうとする試みが ある。しかし，奏効率は総じて低いため(Table 2)，一 般的には行われていない. 肝硬変症例が多いため継続 しにくいこともあり，少なくとも生体肝移植において は十分なデー夕の集積はない.

\section{2. 免疫抑制剤}

肝炎再燃によるグラフトロスを防ぐために，移植後 の免疫抑制を steroid free とする試みが広まりつつあ るが，一方で，急速にステロイド隇量をした方が肝炎 
Table 2 Pretransplant treatment for $\mathrm{HCV}$

\begin{tabular}{|c|c|c|c|}
\hline & Crippin 23) & Everson 24) & Forns 25$)$ \\
\hline No of patients & 15 & 102 & 30 \\
\hline Treatment & IFN & $\mathrm{IFN}+\mathrm{RBV}$ & $\mathrm{IFN}+\mathrm{RBV}$ \\
\hline Response rate $(\%)$ & 33 & 20 & 30 \\
\hline Relapse rate among the responders $(\%)$ & Not described & 50 & 33 \\
\hline
\end{tabular}

Table 3 Peginterferon alfa-2b and ribavirin combination for HCV recurrence after liver transplantation

\begin{tabular}{|c|c|c|c|c|c|c|c|}
\hline \multirow[b]{2}{*}{ Study } & \multirow[b]{2}{*}{ Year } & \multirow[b]{2}{*}{$\mathrm{N}$} & \multirow[t]{2}{*}{ Duration (M) } & \multicolumn{2}{|l|}{ Treatment } & \multicolumn{2}{|l|}{ Eradication } \\
\hline & & & & Peg IFN & $\begin{array}{l}\text { Ribavirin } \\
\text { (mg/day) }\end{array}$ & $\begin{array}{l}\text { At the end } \\
\text { of treatment }\end{array}$ & Sustained \\
\hline Mukherjee ${ }^{26)}$ & 2003 & 39 & Not described & $1.5 \mathrm{mcg} / \mathrm{kg} / \mathrm{w}$ & 800 & $38 \%$ & $31 \%$ \\
\hline Neff 27$)$ & 2004 & 57 & 12 & $1.5 \mathrm{mcg} / \mathrm{kg} / \mathrm{w}$ & $400--600$ & $25 \%$ & Not described \\
\hline Rodriguez-Luna ${ }^{28)}$ & 2004 & 33 & 12 & $0.5-1.5 \mathrm{mcg} / \mathrm{kg} / \mathrm{w}$ & $400--1000$ & $37 \%$ & $26 \%$ \\
\hline Ross 29$)$ & 2004 & 16 & 12 & $1.5 \mathrm{mcg} / \mathrm{kg} / \mathrm{w}$ & $800-1000$ & $38 \%$ & Not described \\
\hline Dumortier ${ }^{30)}$ & 2004 & 20 & 28 & $0.5-1 \mathrm{mcg} / \mathrm{kg} / \mathrm{w}$ & $400-1200$ & $55 \%$ & $45 \%$ \\
\hline Chalasani 31) & 2005 & 33 & 12 & $180 \mathrm{mcg}$ & Not described & $27 \%$ & $12 \%$ \\
\hline
\end{tabular}

再燃の危険が高かったとする報告もあり14)，早期ステ ロイド離脱の有效性, 安全性は今後も議論を重故る必 要がある.サイクロスポリンの抗ウイルス効果に関し ては意見の一致をみていない15). 教室では, C 型肝炎 陽性症例に対し, 免疫抑制剤のプロトコールを変更し ていない.

\section{3. 肝炎再発判定と治療時期}

再発の診断基準は，欧米ではトランスアミナーゼの 正常上限の 2-3 倍で, 肝生検にて肝炎の所見があるも のと定義されている. Ghobrial ら16) は脳死肝移植患者 に扔いて, HCV の再発時期が HCV 陽性症例の予後因 子になっていると報告した. 特に移植後 1 年以内に再 発した症例では，5年累積患者生存率，グラフト生着率 は各々約 $60 \%, 52 \%$ と, それ以降に再発した症例に比 べ有意に予後不良である. HCV 陽性症例では, $\mathrm{HCV}$ 再感染対策を十分に行わないと, 良好な予後は見込め ない订能性がある.さまざまな予後不良因子の中で, ドナ一年齢が注目されている17)。また, 生体肝移植の ほうが, 果たして脳死肝移植よりも再発時期が早く, 予後不良なのか，いまだ議論のあるところではっきり しない. 米国での大規模比較試験 (A2ALL)の結果を待 ちたい18).

高ウイルス価が長期間継続すると急速に黄疸が進行 し, いわゆる cholestatic hepatitis ${ }^{19)} に$ 移行すること
がある、組織学的には，細胆管の破壊像，門脈領域の

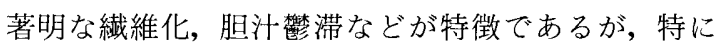
cholestatic hepatitisに特異的なものはない，抗ウイル 療法に反応するものもあるが，一般的には極めて予 後不良であり，再移植しても良好な結果は望みにくい.

現在では, ペグインターフェロンとリバビリンとの 併用療法が再発治療のスタンダードである(Table 3). Bizollon 20) らは再発症例に対し, 併用療法を 6 力月, さらにリバビリンのみを 12 力月行ったところ，18 カ月 の治療終了後 6 力月後, 血液中 HCV が陰性であった 症例は $26 \%(14 / 54)$ であったと報告している。さらに 14 症例中 13 例では血中やグラフト中の HCV 陰性が 3 年 間持続した。現在の併用療法の問題点は, その副作月丁 のため, 長期間の継続は容易ではないことである。

\section{4. 予防的治療}

脳死肝移植では，再発の有無にかかわらず抗ウイル ス治療を行うが，予防的治療はあまり一般的ではない。 教室では, 生体肝移植症例に打いて, 早期より予防療 法に努めてきた21). 全例で術後 1-2 力月をめどにイン ターフェロン alpha $2 \mathrm{~b}$ とリバビリンによる併用然法を 行っている. インターフェロン alpha 2b は 300 万単位 週 3 回, リバビリンは $400 \mathrm{mg} /$ 日からスタートし, 骨髄 抑制，うつ傾向，溶血性貧血などの重篤な合併疗の出 現の有整を確認し, 問題なければ, 各々, 600 万単位週 
3 回, リバビリンは $600 \mathrm{mg} /$ 日にドーズアップしている. 刘象症例は 51 例で, sustained viral response rate は $31 \%$ (geno type 1b では 29\%) であり，概ね満足すべき ものであった。

\section{おわりに}

ウイルス肝炎朋硬変に対する肝移植について概説し た. HBV 陽性症例では HBIGのコストの問題と, 今後 增加すると予想される術前加らの変異株陽性症例の対 策が問題となる. HCV 陽性症例ではぺグインターフェ ロンとリバビリンの併用療法に代わる, より奏効率が 占く, 副作用が少ない治療法の開発が望まれる状沿で ある。

謝辞 : 本研究の一部は厚生労衝科学研究費補助金工イ ズ刘策研究事業「HIV 感染症に合併する朋聅患に関する研 究」, 難治性疾患克服研究事業「難治性の肝疾患に関する 調查研究」, 肝炎等克服緊急対策事栄 (肝炎分野)「C 型朋 炎への朋移植後の免炈抑制法に関する研究」，文部科学省 科学研究費補助金に拠った。

\section{文献}

1) Samuel D, Muller R, Alexander G, et al. Liver transplantation in European patients with the hepatitis $B$ surface antigen. $N$ Engl J Med $1993 ; 329: 1842-7$

2) Papatheodoridis GV, Sevastianos V, Burroughs AK. Prevention of and treatment for hepatitis $B$ virus infection after liver transplantation in the nucleoside analogues era. Am J Transplant $2003: 3: 250-8$

3) Lo CM, Fung JT, Lau GK, et al. Development of antibody to hepatitis $B$ surface antigen after liver transplantation for chronic hepatitis $B$. Hepatology $2003: 37: 36-43$

4) Johnson PJ, Wansbrough-Jones MH, Portmann B, et al. Familial HBsAg-positive hepatoma: treatment with orthotopic liver transplantation and specific immunoglobulin. Br Med J 1978 ; l (6107) : 216

5) Shouval D, Samuel D. Hepatitis B immune globulin to prevent hepatitis B virus graft reinfection following liver transplantation: a concise review. Hepatology $2000 ; 32: 1189-95$

6) Buti M, Mas A, Prieto $M$, et al. A randomized study comparing lamivudine monotherapy after a short course of hepatitis B immune globulin (HBIg) and lamivudine with longterm lamivudine plus HBIg in the prevention of hepatitis $B$ virus recurrence after liver transplantation. J Hepatol $2003 ; 38: 811-7$

7) Sugawara Y, Makuuchi M, Kaneko J, et al. Living donor liver transplantation for hepatitis B cirrhosis. Liver Transpl 2003 : $9: 1181-4$

8) Chan HL, Chui AK, Lau WY, et al. Outcome of lamivudine resistant hepatitis $B$ virus mutant post-liver transplantation on lamivudine monoprophylaxis. Clin Transplant $2004 ; 18: 295-$ 300

9) Schiff ER, Lai CL, Hadziyannis $S$, et al. Behalf of the Adefovir Dipovoxil Study 435 International Investigators Group. Adefovir dipivoxil therapy for lamivudine-resistant hepatitis B in pre- and post-liver transplantation patients. Adefovir dipivoxil therapy for lamivudineresistant hepatitis $B$ in pre- and post-liver transplantation patients. Hepatology 2003 ; $38: 1419-27$

10) Sanchez-Fueyo A, Rimola A, Grande L, et al. Hepatitis $\mathrm{B}$ immunoglobulin discontinuation followed by hepatitis $B$ virus vaccination: $A$ new strategy in the prophylaxis of hepatitis $B$ virus recurrence after liver transplantation. Hepatology $2000 ; 31: 496--501$

11) Sanchez-Fueyo A, Martinez-Bauer E, Rimola A. Hepatitis $B$ vaccination after liver transplantation. Hepatology $2002 ; 36: 257-58$

12) Barcena R, Fernandez-Braso M, Urman J, et al. Response to hepatitis $B$ virus vaccine in patients transplanted for HBV-related liver disease under specific gammaglobulin prophylaxis. Transplant Proc $1999 ; 31: 2459-60$

13) Bienzle U, Gunther M, Neuhaus R, et al. Immunization with an adjuvant hepatitis $B$ vaccine after liver transplantation for hepatitis $B$. related disease. Hepatology $2003: 38: 811-9$

14) Brillanti $S$, Vivarelli $M$, De Ruvo $N$, et al. Slowly tapering off steroids protects the graft against hepatitis $\mathrm{C}$ recurrence after liver transplantation. Liver Transpl $2002 ; 8: 884-8$

15) Martin P, Busuttil RW, Goldstein RM, et al. Impact of tacrolimus versus cyclosporine in 
hepatitis $\mathrm{C}$ virus-infected liver transplant recipients on recurrent hepatitis: a prospective, randomized trial. Liver Transpl $2004 ; 10: 1258-$ 62

16) Ghobrial RM, Steadman R, Gornbein J, et al. A 10-year experience of liver transplantation for hepatitis $\mathrm{C}$ : analysis of factors determining outcome in over 500 patients. Ann Surg 2001 ; $234: 384-93$

17) Machicao VI, Bonatti $H$, Krishna $M$, et al. Donor age affects fibrosis progression and graft survival after liver transplantation for hepatitis C. Transplantation 2004; $77: 84-92$

18) Brown RS Jr. Is recurrence of hepatitis $C$ worse after living donor or deceased donor liver transplantation? Liver Transpl $2004 ; 10$ : 1256-7

19) Lim HL, Lau GK, Davis GL, et al. Cholestatic hepatitis leading to hepatic failure in a patient with organ-transmitted hepatitis $\mathrm{C}$ virus infection. Gastroenterology $1994 ; 106: 248-51$

20) Bizollon T, Ahmed SN, Radenne S, et al. Long term histological improvement and clearance of intrahepatic hepatitis C virus RNA following sustained response to interferon-ribavirin combination therapy in liver transplanted patients with hepatitis $\mathrm{C}$ virus recurrence. Gut $2003 ; 52: 283-7$

21) Sugawara $Y$, Makuuchi M, Matsui $Y$, et al. Preemptive therapy for hepatitis $\mathrm{C}$ virus after living-donor liver transplantation. Transplantation $2004 ; 78: 1308-11$

22) Angelico M, Di Paolo D, Trinito MO, et al. Failure of a reinforced triple course of hepatitis $B$ vaccination in patients transplanted for HBV-related cirrhosis. Hepatology $2002 ; 35$ : 176--81

23) Crippin JS, McCashland T, Terrault N, et al. A pilot study of the tolerability and efficacy of antiviral therapy in hepatitis C virus-infected patients awaiting liver transplantation. Liver
Transpl $2002: 8: 350--5$

24) Everson G, Trouillot $T$, Trotter J, et al. Treatment of decompensated cirrhosis with a low accelerating dose regimen of interferon-alpha 2b plus ribavirin: safety and efficacy. Hepatology $2001: 32: 595 \mathrm{~A}$

25) Forns $X$, Garcia-Retortillo M, Serrano $T$, et al. Antiviral therapy of patients with decompensated cirrhosis to prevent recurrence of hepatitis $\mathrm{C}$ after liver transplantation. J Hepatol $2003 ; 39: 389-96$

26) Mukherjee S, Rogge J, Weaver L, et al. Pilot study of pegylated interferon alfa-2b and ribavirin for recurrent hepatitis $\mathrm{C}$ after liver transplantation. Transplant Proc 2003; 35 : 3042-4

27) Neff GW, Montalbano M, O'Brien CB, et al. Treatment of established recurrent hepatitis $C$ in liver-transplant recipients with pegylated interferon-alfa-2b and ribavirin therapy. Transplantation $2004 ; 78: 1303-7$

28) Rodriguez-Luna $\mathrm{H}$, Khatib $\mathrm{A}$, Sharma $\mathrm{P}$, et al. Treatment of recurrent hepatitis $\mathrm{C}$ infection after liver transplantation with combination of pegylated interferon alpha $2 \mathrm{~b}$ and ribavirin: an open-label series. Transplantation $2004 ; 77$ : $190-4$

29) Ross AS, Bhan AK, Pascual M, et al. Pegylated interferon alpha- $2 \mathrm{~b}$ plus ribavirin in the treatment of post-liver transplant recurrent hepatitis C. Clin Transplant $2004 ; 18: 166-73$

30) Dumortier J, Scoazec JY, Chevallier P, et al. Treatment of recurrent hepatitis $\mathrm{C}$ after liver transplantation: a pilot study of peginterferon alfa- $2 \mathrm{~b}$ and ribavirin combination. J Hepatol $2004 ; 40: 669-74$

31) Chalasani N, Manzarbeitia $C$, Ferenci $P$, et al. Pegasys Transplant Study Group. Peginterferon alfa-2a for hepatitis $\mathrm{C}$ after liver transplantation: two randomized, controlled trials. Hepatology $2005 ; 41: 289-98$ 